\title{
Giant Viruses of Amoebae as Potential Human Pathogens
}

\author{
Philippe Colson ${ }^{\mathrm{a}, \mathrm{b}}$ Bernard La Scola ${ }^{\mathrm{a}, \mathrm{b}}$ Didier Raoult ${ }^{\mathrm{a}-\mathrm{c}}$ \\ aURMITE UM63, CNRS 7278, IRD 198, INSERM U1905, Institut Hospitalo-Universitaire Méditerranée Infection, \\ Facultés de Médecine et de Pharmacie, Aix-Marseille Université, and b Pôle des Maladies Infectieuses et Tropicales \\ Clinique et Biologique, Fédération de Bactériologie-Hygiène-Virologie, Centre Hospitalo-Universitaire Timone, \\ Institut Hospitalo-Universitaire Méditerranée Infection, Marseille, France; ' Special Infectious Agents Unit, \\ King Abdulaziz University, Jeddah, Saudi Arabia
}

\section{Key Words}

Mimivirus · Marseillevirus · Mimiviridae · Marseilleviridae · Megavirales · Amoeba $\cdot$ Humans $\cdot$ Pathogenicity $\cdot$ Disease

\begin{abstract}
Giant viruses infecting phagocytic protists are composed of mimiviruses, the record holders of particle and genome size amongst viruses, and marseilleviruses. Since the discovery in 2003 at our laboratory of the first of these giant viruses, the Mimivirus, a growing body of data has revealed that they are common inhabitants of our biosphere. Moreover, from the outset, the story of Mimivirus has been linked to that of patients exhibiting pneumonia and it was shown that patients developed antibodies to this amoebal pathogen. Since then, there have been several proven cases of human infection or colonization with giant viruses of amoebae, which are known to host several bacteria that are human pathogens. Mimiviruses and marseilleviruses represent a major challenge in human pathology, as virological procedures implemented to date have not used appropriate media to allow their culture, and molecular techniques have used filtration steps that likely prevented their detection. Nevertheless, there is an increasing body of evidence that mimiviruses might cause pneumonia and that humans carry marseilleviruses, and re-analyses of metagenomic databases have provided
\end{abstract}

evidence that these giant viruses can be common in human samples. The proportion of human infections related to these giant mimiviruses and marseilleviruses and the precise short- and long-term consequences of these infections have been scarcely investigated so far and should be the subject of future works.

(c) 2013 S. Karger AG, Basel

\section{Introduction}

At the origin of the assessment of the role of Mimivirus in pneumonia, a misunderstanding occurred. Tom Marrie managed a collection of serum samples from patients presenting with pneumonia of unknown aetiology, and we had postulated that bacteria resistant to amoebae of the Acanthamoeba species, such as Legionella pneumophila, were potential causative agents of pneumonia [1$5]$. We began this work with interesting results that showed serological reactions against new species of $L e$ gionella and Parachlamydia that we discovered through a collaboration with Tim Rowbotham, who had sent us a collection of Legionella-like amoebal pathogens. Interestingly, the microorganism that showed the most serological reactivity was Bradford coccus [6,7]. In the course of analysing the results, it became clear that Bradford coccus

\begin{tabular}{ll}
\hline KARGER & $\begin{array}{l}\text { () 2013 S. Karger AG, Basel } \\
0300-5526 / 13 / 0566-0376 \$ 38.00 / 0 \quad \text { Karger }\end{array}$ \\
$\begin{array}{l}\text { E-Mail karger@karger.com } \\
\text { www.karger.com/int }\end{array}$ & $\begin{array}{l}\text { This is an Open Access article licensed under the terms of the } \\
\text { Creative Commons Attribution-NonCommercial 3.0 Un- } \\
\text { ported license (CC BY-NC) (www.karger.com/OA-license), } \\
\text { applicable to the online version of the article only. Distribu- } \\
\text { tion permitted for non-commercial purposes only. }\end{array}$
\end{tabular}

Prof. Didier Raoult, $\mathrm{MD}, \mathrm{PhD}$

Unité des Rickettsies, URMITE UM63, CNRS 7278, IRD 198, INSERM U1095

Faculté de Médecine, Aix-Marseille Université

27, boulevard Jean-Moulin, FR-13385 Marseille Cedex 05 (France)

E-Mail didier.raoult@gmail.com 


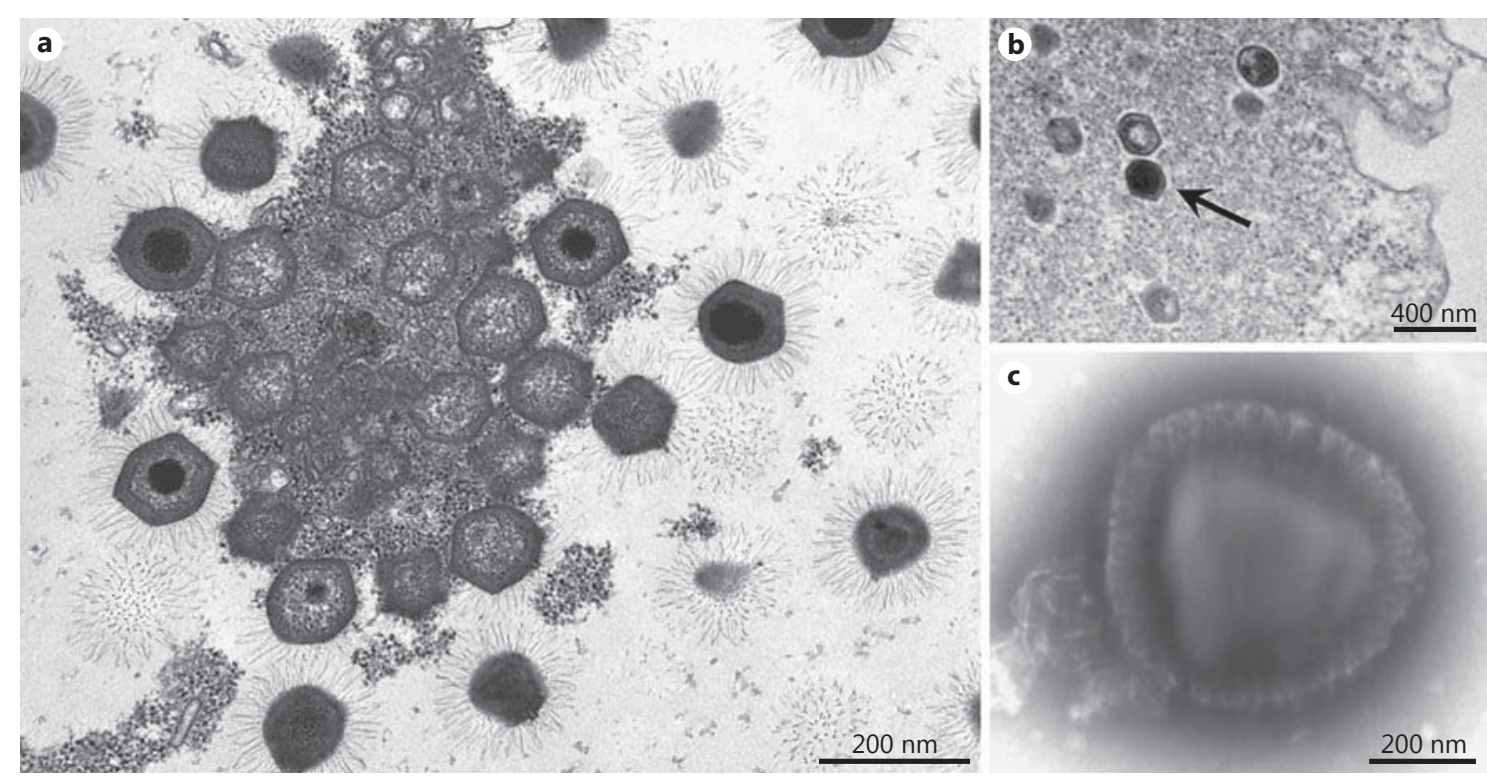

Fig. 1. Electron micrographs of the Mimivirus factory inside Acanthamoeba spp. (a; transmission electron microscopy), Senegalvirus particles (b; transmission electron microscopy; a particle is shown by the arrow), and LBA111 virus particle (c; negative staining).

was not a bacterium but the first amoeba-infecting giant virus. We named it Mimivirus for several reasons, including its mimicry of a bacterium by its size and appearance by Gram staining [6]. Therefore, while focusing on the remarkable features of Mimivirus, we postponed the publication of the results on Mimivirus seropositivity in patients with pneumonia $[8,9]$. Thus, from the outset, while Mimivirus was still thought to be a coccus, we knew that there were antibodies to this amoebal pathogen.

\section{The Mimivirus Discovery}

Mimivirus was discovered in 2003 in the Rickettsia laboratory at the Marseille School of Medicine [7]. However, it was isolated 20 years ago in the centre of England, and its story was immediately linked to episodes of pneumonia $[6,7]$. Indeed, Tim Rowbotham and his collaborators at the Public Health Laboratory in Leeds, UK, investigated a 1992 pneumonia outbreak in Bradford for which no causative agent was identified. These researchers showed the utility of culturing on Acanthamoeba spp., which are ubiquitous amoebae living in water and soil, to isolate agents of pneumonia, including L. pneumophila, from human samples [10-15]. These amoebae are phagocytic protists that have been described as true Trojan horses because they can host multiple human pathogen- ic bacteria that survive and multiply within the amoebae and are protected from various external physical and chemical agents when the amoebae encyst $[1,16-21]$. Therefore, to isolate the bacteria causing the pneumonia outbreak in Bradford, Rowbotham inoculated amoebae with water from cooling towers, which he thought might be the origin of the epidemic [7]. The presence of an amoebal pathogen was visualized by the formation of lysis plaques due to the multiplication of the microorganism. Several pathogens of amoebae were isolated by this strategy from environmental samples collected in Bradford. In 1995, Richard J. Birtles, a young English investigator, conducted a postdoctoral fellowship in our lab and brought this particular collection of microorganisms isolated by amoebal coculture. Several new Legionella species were characterized, including L. rowbothamii, L. drozanskii, L. fallonii, and L. drancourtii [4, 22]. Another of the amoebal pathogens had the appearance of a Grampositive coccus and was named Bradford coccus [7]. Surprisingly, it resisted various strategies aimed at its identification, including the PCR amplification and sequencing of the $16 \mathrm{~S}$ ribosomal DNA. These unexpected failures led to the observation of Bradford coccus using electron microscopy, which revealed that it had an icosahedral structure strongly suggestive of a virus (fig. 1a). Subsequently, the viral nature of Bradford coccus was confirmed by observations, including an eclipse phase dur- 


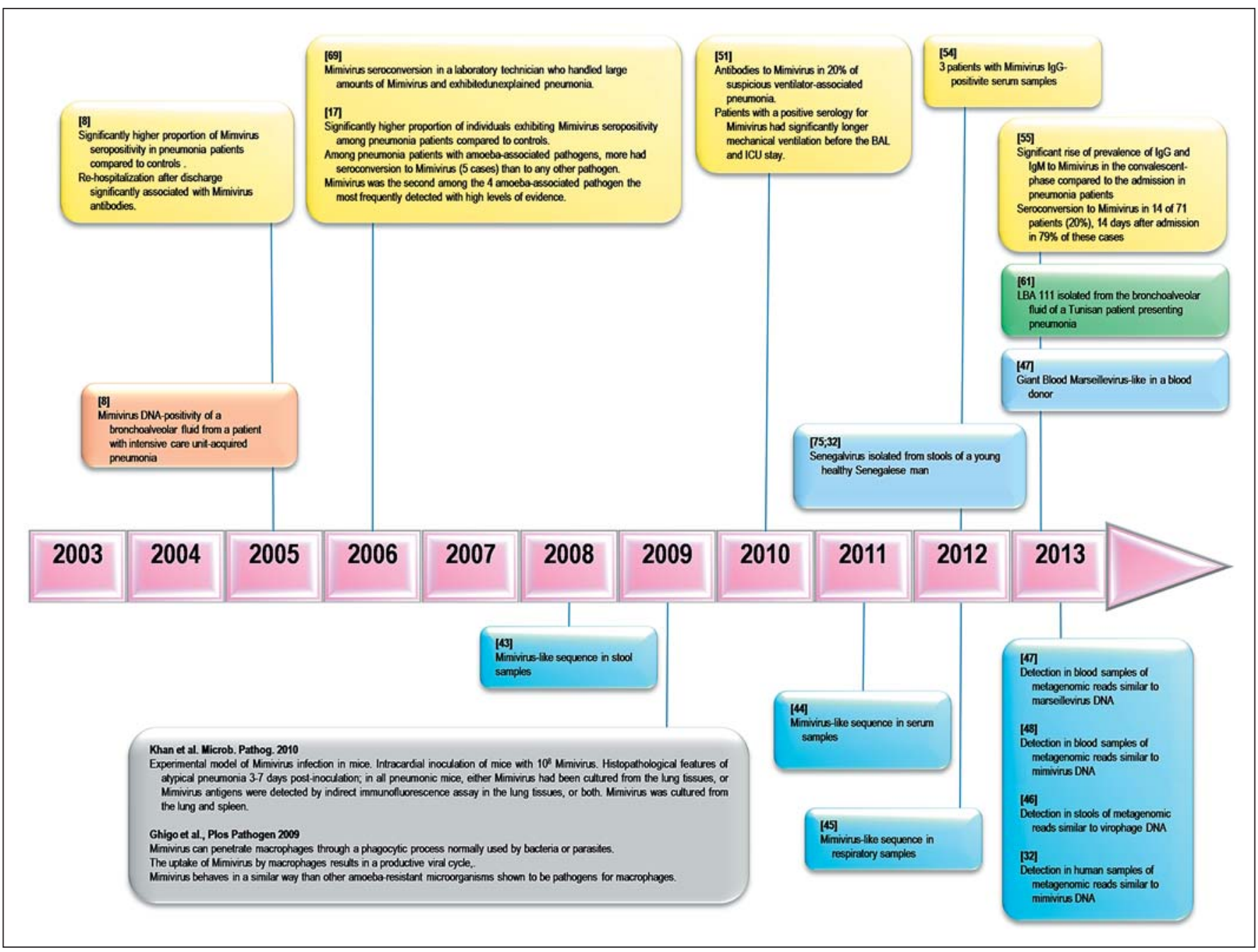

Fig. 2. Timeline of evidence indicating that mimiviruses are causative agents of pneumonia and that marseilleviruses are present in humans. Giant virus detection by serological testing, PCR testing, culture on Acanthamoeba spp. and metagenomics are indicated by yellow, orange, green and blue backgrounds, respectively. Experimental findings are indicated by a purple background.

ing its replication cycle [6], and by genome sequencing and analyses [23]. Thus, Bradford coccus was renamed as Mimivirus [7].

\section{Metagenomic, Serological and Epidemiological Findings Related to the Exposure of Humans to Mimiviruses, Marseilleviruses and Virophages}

Several metagenomic studies have revealed the presence in environmental samples of sequences that are similar to genomes of amoebal viruses. Reads matching the DNA of mimiviruses and their virophages have been detected from various environmental sources, including water from cooling towers, rivers, lakes and seas [24-32] (fig. 2). In addition, mimiviruses, Mimivirus virophages and marseilleviruses have been isolated from water or soil samples throughout the world [6, 33-41] (fig. 2). Also, Mimivirus-like particles were observed by light microscopy inside acanthamoebae in treated sewage sludge from a wastewater treatment plant in the West Midlands, UK [42]. This finding raised the question of whether dissemination of mimiviruses to agricultural land and surface waters may occur. Taken together, these data indicate that amoebae-infecting viruses are likely to be common inhabitants of our biosphere. Re- 


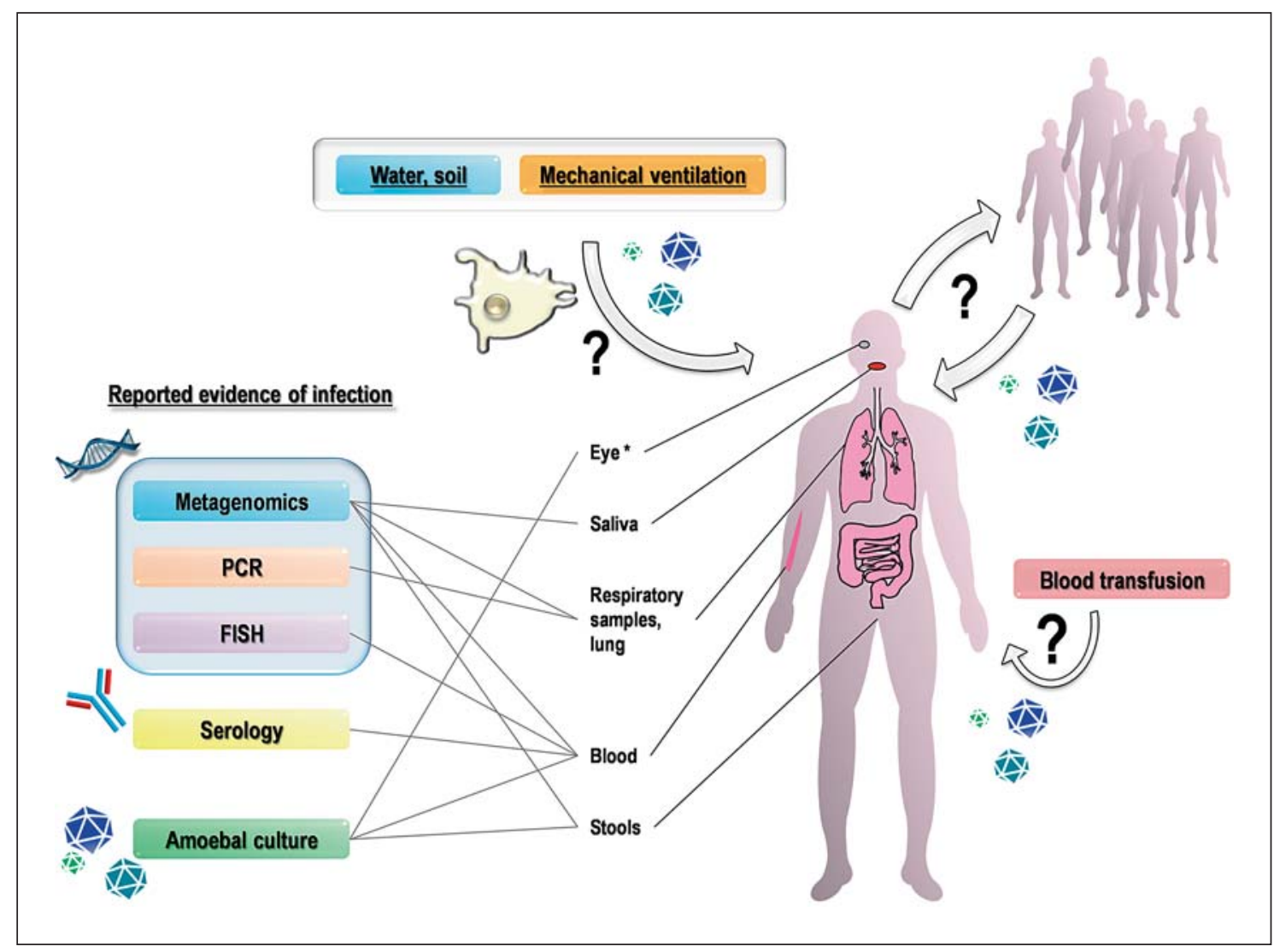

Fig. 3. Schematic diagram of hypotheses and evidence regarding the transmission and detection of giant viruses of amoebae and their associated virophages in humans. ${ }^{*}$ Contact lens storage case liquid. FISH $=$ Fluorescence in situ hybridization.

cently, metagenomic reads matching the genomes of mimiviruses have been identified in various human samples, including faeces, respiratory samples and blood [32, 43-48] (fig. 2, 3). Moreover, it is worth underlining that the prevalence of giant viruses of phagocytic protists has likely been underestimated in metagenomic studies, because the majority of samples analysed over the last decade were passed through filters with 0.22 - to $0.45-\mu \mathrm{m}$ pores before viral metagenomic investigations, which could considerably hamper the detection of the largest viruses $[49,50]$.

Three studies have used serology to assess the prevalence of infections with mimiviruses in patients living in France and Canada during the $2005-2010$ period $[8,17$, 51-53] (fig. 2, 3). Since then, two additional studies have been conducted in patients with chronic obstructive pulmonary disease in the Netherlands [54] and in intensive care unit (ICU) pneumonia patients in southeastern France [55]. In all these studies, Mimivirus serology was tested in our laboratory by a microimmunofluorescence test. The prevalence of IgG ranged from $0 \%$ in 8 patients exhibiting aspiration pneumonia [55] to $25 \%$ in 8 patients at an acute phase of non-ventilator-associated pneumonia acquired at a hospital ICU [55]. In most cases, the IgG prevalence measured in pneumonia patients was approximately $10-20 \%$. This prevalence was $2.5 \%$ among patients with chronic obstructive pulmonary disease in the Netherlands, and 6.7\% during an exacerbation episode [54]. In addition, Bousbia et al. [55] showed additional data that support the role of mimiviruses in hospital-acquired pneumonia. Thus, a significant rise of prevalence of both IgG and IgM to Mimivirus was observed in the convalescent-phase serum samples compared to the admission serum samples. In this study, seroconversion to Mimivirus was described in 14 out of 71 patients (20\%) with paired serum samples, and occurred 14 days after admission in $79 \%$ of these cases. As a comparison, $0 \%$ of intubated control patients without pneumonia in ICUs 
and $2.3 \%$ of healthy control subjects in Nova Scotia [8] had IgG to Mimivirus.

Acanthamoeba spp. may play a significant role in the transmission of mimiviruses (fig. 3). These free-living amoebae are ubiquitous organisms that are predominant organisms in soil and water and can resist various unfavourable conditions as cysts $[1,16,56]$. As trophozoites, Acanthamoeba spp. are phagocytic protists that can host algae, fungi, yeasts, bacteria and viruses $[1,16,56]$. However, some bacteria, as well as mimiviruses and marseilleviruses, can resist and multiply into acanthamoebae, which, in such cases, have a role of replicative niche, reservoir, armour and vector $[1,16,20]$. Amoeba-resisting microorganisms live sympatrically in their host, with considerable opportunities to exchange genes, and such lifestyle has been shown to generate large genomes with a mosaic gene repertoire $[57,58]$. Furthermore, three points are worth emphasizing with respect to the clinical relevance of giant viruses associated with amoebae. First, several amoebae-resisting bacteria, including Legionella spp. and Mycobacterium spp., are human pathogens, which supports the paradigm that describes Acanthamoeba spp. as Trojan horses $[1,16]$. Second, it has been proposed that amoebae may be training fields for resistance to macrophages based on the fact that some of these bacteria also resist degradation by macrophages $[1,59]$. Third, it has been previously pointed out that persons with a high risk of infection by Mimivirus likely were exposed to water contaminated by Acanthamoeba spp. [8, $52,55]$. This includes patients with ventilator-associated pneumonia that is associated with exposure to hospital water supplies $[8,17,60]$. More generally, risk factors for infection with mimiviruses may be similar to those identified for other microorganisms, such as L. pneumophila, which are resistant to amoebae and are human pathogens $[8,17]$ (fig. 2).

\section{Evidence of Human Infection or Colonization with a Giant Virus}

Mimivirus DNA has been detected only twice from the bronchoalveolar fluid of pneumonia patients $[8,61]$, although PCR testing has been performed in five studies that investigated the role of Mimivirus in respiratory infections [8, 62-65]. Nevertheless, it is worth noticing that only three PCR systems were used in these studies and they only targeted the Mimivirus genome obtained in 2004 [23]. The family Mimiviridae has expanded since 2004 and genetic diversity has been shown to be substan- tial between mimiviruses [66, 67], and, therefore, these PCR assays should have had limited or no efficiency to detect other Mimivirus DNA than that of the first Mimivirus strain [68].

The first proven case of infection with a giant virus of amoebae involved one of our laboratory technicians who handled large amounts of Mimivirus to perform Western blot assays [69] (table 1; fig. 2, 3). This technician habitually made an annual check of his serologies to the microbes he manipulated. Mimivirus is known for its extreme resistance to degradation by physical and chemical agents [70], and amoebae can also protect them from degradation $[71,72]$. The technician came for medical consultation with one of us (D.R.) for an unexplained respiratory infection, which was verified by a chest X-ray that showed bilateral basilar infiltrates suggesting viral pneumonia, and did not improve with 1 -week administration of amoxicillin-clavulanic acid [69]. This technician concurrently seroconverted against Mimivirus. Using twodimensional gel electrophoresis and Western blotting analyses on his 2 sera collected before and during pneumonia, we showed that the laboratory worker had seroconverted for total antibodies against 23 Mimivirus proteins, including 4 unique to Mimivirus. These findings established a true experimental model of human infection by Mimivirus, with specific serological reactivity and a disease that also appeared to be specific, as it was not cured by antibiotics, and no other potential agents of pneumonia were found.

A second association of a giant virus of amoebae with human was that of Lentillevirus, a new Mimivirus strain that was recovered from the contact lens storage case liquid of a 17-year-old myopic woman presenting with keratitis and for whom no bacteria or Acanthamoeba were detected in a corneal scraping [73]. Pseudomonas fluorescens, Stenotrophomonas maltophilia, Mycobacterium chelonae and Acanthamoeba polyphaga were detected from the liquid. Unexpectedly, we also isolated from this liquid Lentillevirus infecting the amoeba together with a new virophage of giant virus, which was named Sputnik 2 , and previously undescribed bacterial symbionts of the amoeba $[35,73,74]$.

The third evidence of human exposure to Mimivirus in association with clinical symptoms was provided by a young couple living in France who had travelled to Laos, their country of origin [31]. In Laos, the couple ate whole raw fish (a common practice in Laos) from the Mekong River. The 29-year-old woman and the 32-year-old man were admitted to Marseille University hospital on day 7 after the onset of unexplained symptoms that included 


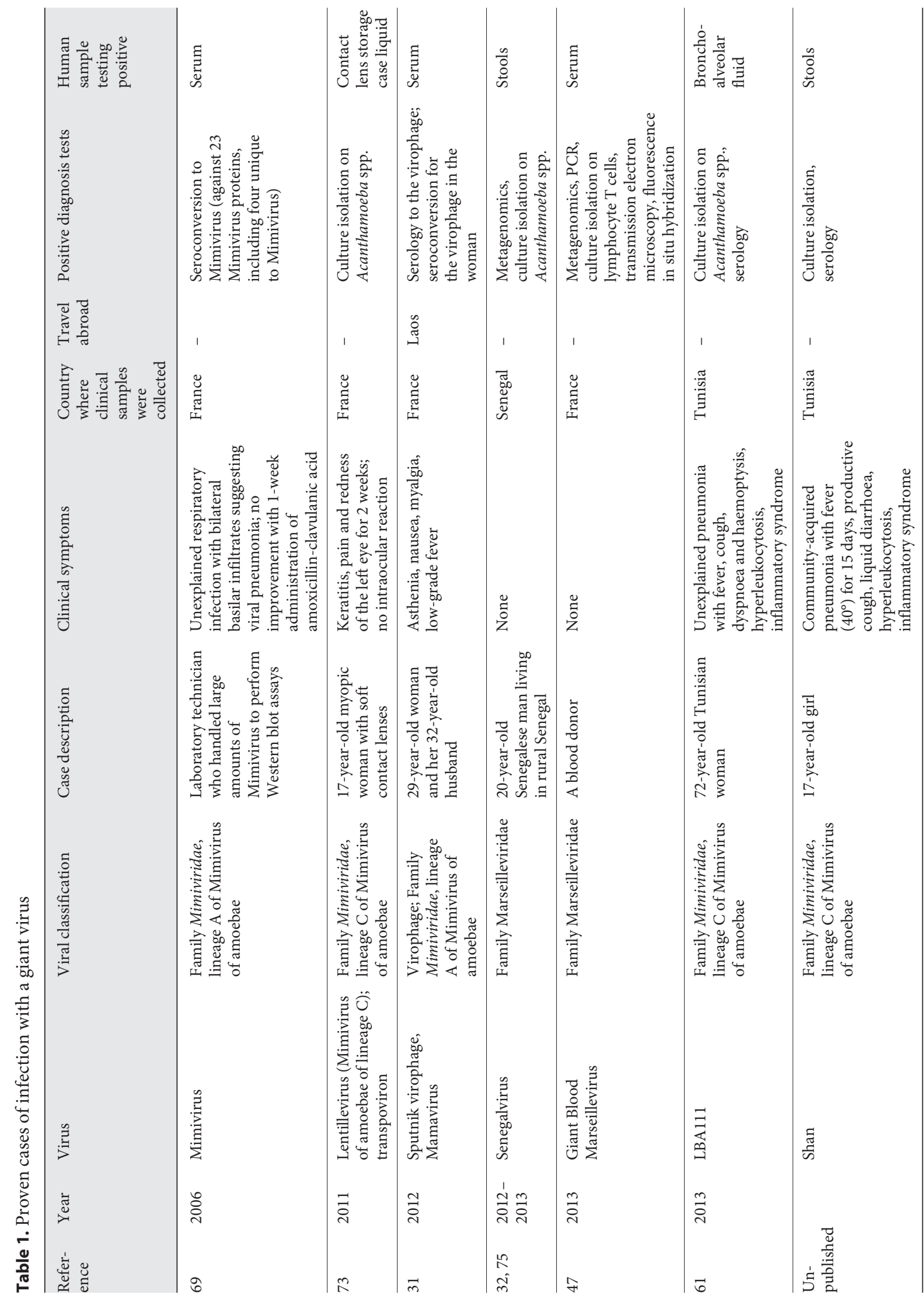


asthenia, nausea, myalgia and low-grade fever. We performed multiple serologies, and at that time, we were systematically testing serum samples for the presence of antibodies to the Sputnik virophage of Mimivirus [33]. Thus, we were able to discover that both patients had positive serologies for the virophage. In addition, because serum samples had been collected from the woman 5 months earlier during her pregnancy, we could demonstrate that she exhibited seroconversion for the virophage. Western blotting, two-dimensional gel electrophoresis and matrix-assisted laser desorption ionization mass spectrometry confirmed the specificity of the serological reactivity and identified that it targeted two virophage proteins. Moreover, we detected in both patients weak serological reactivity against Mamavirus, another strain of Mimivirus [33], and against A. castellanii. Various samples collected from the 2 patients during their follow-up were negative. Full recovery was observed for these patients, who received antiparasitic therapy due to positive serologies for Toxocara, Trichinella and Fasciola trematodes.

A fourth case consisted of the serendipitous isolation of a Marseillevirus from the stools of a young Senegalese man living in N'Diop, a rural area $[32,75]$, who exhibited no clinical symptoms. Indeed, while investigating the faecal microbiota through a new metagenomic approach that targets $16 \mathrm{~S}$ ribosomal DNA but concurrently performs a full enzymatic digestion of the sample DNA, we generated many metagenomic reads that were initially discarded. Then, we searched these discarded reads in the 'trash' and found sequences matching the Marseillevirus genome, which led to the isolation of a new member of the family Marseilleviridae. This virus was named Senegalvirus and was actually the first Marseillevirus recovered from a human (fig. 1b). Subsequently, we searched for sequences related to members of the Megavirales in several human metagenomes, and we retrieved significant hits among reads recovered from saliva, oropharynx, lung and stools [32], which adds to the results of previous studies identifying sequences related to members of other families of the order Megavirales in human blood, nasopharyngeal samples or stools [43, 45, 76-79].

We recently described a fifth case that consisted of human infection by a giant virus of amoebae that was identified during a metagenomic study conducted on virally enriched blood fractions collected from blood donors [47]. In that study, the human virome was investigated using filters with a pore size of $0.45 \mu \mathrm{m}$ but not $0.22 \mu \mathrm{m}$. This enabled the recovery of many sequences, represent- ing $2.5 \%$ of the metagenomic reads, which were similar to Marseillevirus DNA. These sequences could then be assembled into two contigs with sizes of 13.6 and 10.2 $\mathrm{kbp}$ by mapping the reads onto the Marseillevirus genome. Marseillevirus DNA was detected by PCR in the blood from 1 of the 10 blood donors, and high-throughput sequencing generated reads that were assembled into a 357-kbp DNA sequence that was closely related to the Marseillevirus genome as confirmed by phylogeny reconstruction. This new giant virus was named Giant Blood Marseillevirus. In addition, the presence of the virus was confirmed by transmission electron microscopy and fluorescence in situ hybridization, and Giant Blood Marseillevirus virus was cultured from the blood sample on T lymphocyte cells. Finally, in the same study, antibodies to 26 Giant Blood Marseillevirus proteins were identified in the serum samples of the Giant Blood Marseillevirus-infected blood donor, while immunoglobulin $\mathrm{G}$ antibodies to this giant virus were detected in the sera of 3 out of 20 additional blood donors. In 2 of these cases, Giant Blood Marseillevirus DNA was concurrently detected, suggesting that infection with close relatives of Marseillevirus is relatively common among blood donors. Taken together, these findings suggest that this Marseillevirus may not cause clinical symptoms as persons in whom infection has been identified were asymptomatic. Nevertheless, whether primary or chronic infections may be associated with clinical manifestations is currently unknown.

In another recent work analysing 196 respiratory specimens collected from Tunisian patients [61], we diagnosed a case of infection with a new Mimivirus classified in lineage $\mathrm{C}$ and closely related to Megavirus chiliensis [39], whose genome is the largest that has been sequenced to date amongst mimiviruses. This new giant virus was named LBA111 (fig. 1c), as it was isolated from bronchoalveolar fluid collected from a 72-year-old Tunisian woman. This patient was hospitalized due to unexplained pneumonia, with fever, cough, dyspnoea and haemoptysis that was associated with an evocative chest X-ray, hyperleukocytosis and inflammatory syndrome; she also had an unfavourable clinical evolution with antibiotic treatment. LBA111 was isolated by amoebal culture. The genome of this new giant viral strain was then sequenced and was found to be $1.23 \mathrm{Mbp}$ in length, the largest viral genome yet recovered from a human. The genome sequence was original, which excluded the possibility of contamination. In addition, the serum sample of the patient harboured total immunoglobulins to 9 LBA111-specific proteins identified by two-dimensional Western 
blotting. Finally, a new Mimivirus tentatively classified within lineage $C$ and named Shan was isolated from the stools of a Tunisian patient who exhibited pneumonia with poor response to antibacterial drugs [80].

\section{Symptomatic and Asymptomatic Infections by Giant Viruses of Amoebae}

The reports compiled here show, on the one hand, that marseilleviruses were detected in 2 asymptomatic cases. Marseilleviruses may induce symptomatic acute infections followed by a chronic carrier phase, or persons infected with these viruses may never exhibit symptomatic infections. This is the subject of a prospective study in our laboratory. On the other hand, there are clearly symptomatic infections with mimiviruses. It is noteworthy that two experimental studies were conducted with Mimivirus. First, inoculation of Mimivirus to macrophages led to an increase of the number of viral DNA copies [81]. Mimivirus appeared pathogenic for the macrophages, and Mimivirus particles recovered from these cells replicated within amoebae, which suggested that Mimivirus infected the macrophages and led to a productive cycle of viral infection. Secondly, an experimental murine model of infection was developed, which showed that mice infected intracardiacally with Mimivirus developed pneumonia, Mimivirus being re-isolated from and/or its antigens being detected in the lungs [82]. Although, clinical investigations have been scarce so far, overall, we have with Mimivirus all the criteria for pathogenicity of Koch's postulates linking the presence of this virus to pneumo- nia. Thus, this virus has never been isolated outside a pathological context in human respiratory samples, it was isolated from pneumonia patients without finding any other causative agent of this pathology, and, in an experimental infection model in mice, it was able to recapitulate pneumonia and could be re-isolated from the lungs.

\section{Conclusion}

Giant viruses infecting phagocytic protists represent a major challenge in human pathology, as virological procedures implemented to date have not used appropriate media to allow their culture, and molecular techniques have used filtration steps that likely prevented their detection. The proportion of respiratory or other infections related to these giant viruses in humans is currently unknown and should be the subject of future work. However, there is an increasing body of evidence that mimiviruses might cause pneumonia and that humans carry marseilleviruses, and re-analyses of metagenomic databases have provided evidence that these giant viruses can be common in human samples. In conclusion, giant viruses infecting amoebae are emerging pathogens in humans, and their precise short- and long-term roles remain to be determined.

\section{Disclosure Statement}

The authors report no potential conflicts of interest or financial disclosures.

\section{References}

1 Greub G, Raoult D: Microorganisms resistant to free-living amoebae. Clin Microbiol Rev 2004;17:413-433.

-2 Greub G, La Scola B, Raoult D: Amoebae-resisting bacteria isolated from human nasal swabs by amoebal coculture. Emerg Infect Dis 2004;10:470-477.

- 3 Greub G, Raoult D: Rhodobacter massiliensis sp. nov., a new amoebae-resistant species isolated from the nose of a patient. Res Microbiol 2003; 154:631-635.

-4 La Scola B, Birtles RJ, Greub G, Harrison TJ, Ratcliff RM, Raoult D: Legionella drancourtii sp. nov., a strictly intracellular amoebal pathogen. Int J Syst Evol Microbiol 2004;54: 699-703.
5 La Scola B, Boyadjiev I, Greub G, Khamis A, Martin C, Raoult D: Amoeba-resisting bacteria and ventilator-associated pneumonia. Emerg Infect Dis 2003;9:815-821.

-6 La Scola B, Audic S, Robert C, Jungang L, de Lamballerie X, Drancourt M, Birtles R, Claverie JM, Raoult $D$ : A giant virus in amoebae. Science 2003;299:2033.

7 Raoult D, La Scola B, Birtles R: The discovery and characterization of Mimivirus, the largest known virus and putative pneumonia agent. Clin Infect Dis 2007;45:95-102.

$>8$ La Scola B, Marrie TJ, Auffray JP, Raoult D: Mimivirus in pneumonia patients. Emerg Infect Dis 2005;11:449-452.
9 Marrie TJ, Costain N, La Scola B, Patrick W, Forgie S, Xu Z, McNeil SA: The role of atypical pathogens in community-acquired pneumonia. Semin Respir Crit Care Med 2012;33: 244-256.

10 Rowbotham TJ: Isolation of Legionella pneumophila from clinical specimens via amoebae, and the interaction of those and other isolates with amoebae. J Clin Pathol 1983;36:978-986.

11 Rowbotham TJ: Preliminary report on the pathogenicity of Legionella pneumophila for freshwater and soil amoebae. J Clin Pathol 1980;33:1179-1183.

12 Rowbotham TJ: Current views on the relationships between amoebae, legionellae and man. Isr J Med Sci 1986;22:678-689. 
13 Rowbotham TJ: Isolation of 'free-living' amoebae causing human disease. J Med Microbiol 1998;47:937, 939-937, 940.

-14 Birtles RJ, Rowbotham TJ, Raoult D, Harrison TG: Phylogenetic diversity of intra-amoebal legionellae as revealed by $16 \mathrm{~S}$ rRNA gene sequence comparison. Microbiology 1996;142: 3525-3530.

15 Fry NK, Rowbotham TJ, Saunders NA, Embley TM: Direct amplification and sequencing of the $16 \mathrm{~S}$ ribosomal DNA of an intracellular Legionella species recovered by amoebal enrichment from the sputum of a patient with pneumonia. FEMS Microbiol Lett 1991;67: 165-168.

16 Barker J, Brown MR: Trojan horses of the microbial world: protozoa and the survival of bacterial pathogens in the environment. Microbiology 1994;140:1253-1259.

-17 Berger P, Papazian L, Drancourt M, La Scola B, Auffray JP, Raoult D: Ameba-associated microorganisms and diagnosis of nosocomial pneumonia. Emerg Infect Dis 2006;12:248255.

-18 Birtles RJ, Rowbotham TJ, Storey C, Marrie TJ, Raoult D: Chlamydia-like obligate parasite of free-living amoebae. Lancet 1997;349: 925-926.

19 Cosson P, Soldati T: Eat, kill or die: when amoeba meets bacteria. Curr Opin Microbiol 2008;11:271-276.

20 Horn M, Wagner M: Bacterial endosymbionts of free-living amoebae. J Eukaryot Microbiol 2004;51:509-514.

-21 Swanson MS, Hammer BK: Legionella pneumophila pathogesesis: a fateful journey from amoebae to macrophages. Annu Rev Microbiol 2000;54:567-613.

22 Adeleke AA, Fields BS, Benson RF, Daneshvar MI, Pruckler JM, Ratcliff RM, Harrison TG, Weyant RS, Birtles RJ, Raoult D, Halablab MA: Legionella drozanskii sp. nov., Legionella rowbothamii sp. nov. and Legionella fallonii sp. nov.: three unusual new Legionella species. Int J Syst Evol Microbiol 2001;51:1151-1160.

$\checkmark 23$ Raoult D, Audic S, Robert C, Abergel C, Renesto P, Ogata H, La Scola B, Suzan M, Claverie JM: The 1.2-megabase genome sequence of Mimivirus. Science 2004;306:1344-1350.

24 Ghedin E, Claverie JM: Mimivirus relatives in the Sargasso sea. Virol J 2005;2:62.

25 Monier A, Larsen JB, Sandaa RA, Bratbak G Claverie JM, Ogata H: Marine Mimivirus relatives are probably large algal viruses. Virol J 2008;5:12.

26 Claverie JM, Grzela R, Lartigue A, Bernadac A, Nitsche S, Vacelet J, Ogata H, Abergel C: Mimivirus and Mimiviridae: giant viruses with an increasing number of potential hosts, including corals and sponges. J Invertebr Pathol 2009;101:172-180.

27 Kristensen DM, Mushegian AR, Dolja VV, Koonin EV: New dimensions of the virus world discovered through metagenomics. Trends Microbiol 2010;18:11-19.
28 Correa AM, Welsh RM, Vega Thurber RL: Unique nucleocytoplasmic dsDNA and +ssRNA viruses are associated with the dinoflagellate endosymbionts of corals. ISME J 2013; 7:13-27.

29 Williamson SJ, Allen LZ, Lorenzi HA, Fadrosh DW, Brami D, Thiagarajan M, McCrow JP, Tovchigrechko A, Yooseph S, Venter JC: Metagenomic exploration of viruses through out the Indian Ocean. PLoS One 2012; 7:e42047.

30 Desnues C, Boyer M, Raoult D: Sputnik, a virophage infecting the viral domain of life. Adv Virus Res 2012;82:63-89.

- 31 Parola P, Renvoisé A, Botelho-Nevers E, La Scola B, Desnues C, Raoult D: Acanthamoeba polyphaga mimivirus virophage seroconversion in patients returning from Laos. Emerg Infect Dis 2012;18:1500-1502.

32 Colson P, Fancello L, Gimenez G, Armougom F, Desnues C, Fournous G, Yoosuf N, Million M, La Scola B, Raoult D: Evidence of the megavirome in humans. J Clin Virol 2013;57: 191-200.

33 La Scola B, Desnues C, Pagnier I, Robert C, Barrassi L, Fournous G, Merchat M, SuzanMonti M, Forterre P, Koonin E, Raoult D: The virophage as a unique parasite of the giant mimivirus. Nature 2008;455:100-104.

34 Boyer M, Yutin N, Pagnier I, Barrassi L, Fournous G, Espinosa L, Robert C, Azza S, Sun S, Rossmann MG, Suzan-Monti M, La Scola B, Koonin EV, Raoult D: Giant Marseillevirus highlights the role of amoebae as a melting pot in emergence of chimeric microorganisms. Proc Natl Acad Sci USA 2009;106: 21848-21853.

35 La Scola B, Campocasso A, N’Dong R, Fournous G, Barrassi L, Flaudrops C, Raoult D: Tentative characterization of new environmental giant viruses by MALDI-TOF mass spectrometry. Intervirology 2010;53:344353.

36 Thomas V, Bertelli C, Collyn F, Casson N, Telenti A, Goesmann A, Croxatto A, Greub G: Lausannevirus, a giant amoebal virus encoding histone doublets. Environ Microbiol 2011;13:1454-1466.

-37 Fischer MG, Allen MJ, Wilson WH, Suttle CA: Giant virus with a remarkable complement of genes infects marine zooplankton. Proc Natl Acad Sci USA 2010;107:1950819513.

38 Yau S, Lauro FM, DeMaere MZ, Brown MV, Thomas T, Raftery MJ, Andrews-Pfannkoch C, Lewis M, Hoffman JM, Gibson JA, Cavicchioli R: Virophage control of antarctic algal host-virus dynamics. Proc Natl Acad Sci USA 2011;108:6163-6168.

39 Arslan D, Legendre M, Seltzer V, Abergel C, Claverie JM: Distant Mimivirus relative with a larger genome highlights the fundamental features of Megaviridae. Proc Natl Acad Sci USA 2011;108:17486-17491.
40 Yoosuf N, Yutin N, Colson P, Shabalina SA, Pagnier I, Robert C, Azza S, Klose T, Wong J, Rossmann MG, La Scola B, Raoult D, Koonin EV: Related giant viruses in distant locations and different habitats: Acanthamoeba polyphaga moumouvirus represents a third lineage of the Mimiviridae that is close to the Megavirus lineage. Genome Biol Evol 2012;4:1324-1330.

41 Boughalmi M, Saadi H, Pagnier I, Colson P, Fournous G, Raoult D, La Scola B: Highthroughput isolation of giant viruses of the Mimiviridae and Marseilleviridae families in the Tunisian environment. Environ Microbiol 2013;15:2000-2007.

42 Gaze WH, Morgan G, Zhang L, Wellington EM: Mimivirus-like particles in acanthamoebae from sewage sludge. Emerg Infect Dis 2011;17:1127-1129.

43 Finkbeiner SR, Allred AF, Tarr PI, Klein EJ, Kirkwood CD, Wang D: Metagenomic analysis of human diarrhea: viral detection and discovery. PLoS Pathog 2008; 4:e1000011.

- 44 Sullivan PF, Allander T, Lysholm F, Goh S, Persson B, Jacks A, Evengard B, Pedersen NL, Andersson B: An unbiased metagenomic search for infectious agents using monozygotic twins discordant for chronic fatigue. BMC Microbiol 2011;11:2.

45 Lysholm F, Wetterbom A, Lindau C, Darban H, Bjerkner A, Fahlander K, Lindberg AM, Persson B, Allander T, Andersson B: Characterization of the viral microbiome in patients with severe lower respiratory tract infections, using metagenomic sequencing. PLoS One 2012;7:e30875.

46 Zhou J, Zhang W, Yan S, Xiao J, Zhang Y, Li $B$, Pan Y, Wang Y: Diversity of virophages in metagenomic datasets. J Virol 2013;87:42254236.

47 Popgeorgiev N, Boyer M, Fancello L, Monteil S, Robert C, Rivet R, Nappez C, Azza S, Chiaroni J, Raoult D, Desnues C: Giant Blood Marseillevirus recovered from asymptomatic blood donors. J Infect Dis 2013, E-pub ahead of print.

48 Law J, Jovel J, Patterson J, Ford G, O'keefe S, Wang W, Meng B, Song D, Zhang Y, Tian Z, Wasilenko ST, Rahbari M, Mitchell T, Jordan T, Carpenter E, Mason AL, Wong GK: Identification of hepatotropic viruses from plasma using deep sequencing: a next generation diagnostic tool. PLoS One 2013;8:e60595.

-49 Angly FE, Willner D, Prieto-Davo A, Edwards RA, Schmieder R, Vega-Thurber R, Antonopoulos DA, Barott K, Cottrell MT, Desnues C, Dinsdale EA, Furlan M, Haynes M, Henn MR, Hu Y, Kirchman DL, McDole T, McPherson JD, Meyer F, Miller RM, Mundt E, Naviaux RK, Rodriguez-Mueller B, Stevens $\mathrm{R}$, Wegley L, Zhang L, Zhu B, Rohwer F: The GAAS metagenomic tool and its estimations of viral and microbial average genome size in four major biomes. PLoS Comput Biol 2009; 5:e1000593. 
50 Thurber RV, Haynes M, Breitbart M, Wegley L, Rohwer F: Laboratory procedures to generate viral metagenomes. Nat Protoc 2009;4: 470-483.

-51 Vincent A, La Scola B, Forel JM, Pauly V, Raoult D, Papazian L: Clinical significance of a positive serology for mimivirus in patients presenting a suspicion of ventilator-associated pneumonia. Crit Care Med 2009;37:111118.

52 Colson P, Raoult D: Is Acanthamoeba polyphaga Mimivirus an emerging causative agent of pneumonia?; in Scheld WM, Grayson ML, Hughes JM (eds): Emerging Infections 9. Washington, ASM Press, 2010.

53 Vincent A, La Scola B, Papazian L: Advances in Mimivirus pathogenicity. Intervirology 2010;53:304-309.

- 54 Vanspauwen MJ, Franssen FM, Raoult D, Wouters EF, Bruggeman CA, Linssen CF: Infections with mimivirus in patients with chronic obstructive pulmonary disease. Respir Med 2012;106:1690-1694.

-55 Bousbia S, Papazian L, Saux P, Forel JM, Auffray JP, Martin C, Raoult D, La Scola B: Serologic prevalence of amoeba-associated microorganisms in intensive care unit pneumonia patients. PLoS One 2013;8:e58111.

56 Rodriguez-Zaragoza S: Ecology of free-living amoebae. Crit Rev Microbiol 1994;20:225241.

57 Raoult D, Boyer M: Amoebae as genitors and reservoirs of giant viruses. Intervirology 2010; 53:321-329.

58 Moliner C, Fournier PE, Raoult D: Genome analysis of microorganisms living in amoebae reveals a melting pot of evolution. FEMS Microbiol Rev 2010;34:281-294.

-59 Salah IB, Ghigo E, Drancourt M: Free-living amoebae, a training field for macrophage resistance of mycobacteria. Clin Microbiol Infect 2009; 15:894-905.

60 Bousbia S, Papazian L, Saux P, Forel JM, Auffray JP, Martin C, Raoult D, La Scola B: Repertoire of intensive care unit pneumonia microbiota. PLoS One 2012;7:e32486.

61 Saadi H, Pagnier I, Colson P, Kanoun Cherif J, Beji M, Boughalmi M, Azza S, Armstrong N, Robert C, Fournous G, La Scola B, Raoult D: First isolation of Mimivirus in a patient with pneumonia. Clin Infect Dis 2013; 57:e127-e134.
62 Larcher C, Jeller V, Fischer H, Huemer HP: Prevalence of respiratory viruses, including newly identified viruses, in hospitalised children in Austria. Eur J Clin Microbiol Infect Dis 2006;25:681-686.

63 Dare RK, Chittaganpitch M, Erdman DD: Screening pneumonia patients for mimivirus. Emerg Infect Dis 2008;14:465-467.

64 Arden KE, McErlean P, Nissen MD, Sloots TP, Mackay IM: Frequent detection of human rhinoviruses, paramyxoviruses, coronaviruses, and bocavirus during acute respiratory tract infections. J Med Virol 2006;78:12321240.

65 Costa C, Bergallo M, Astegiano S, Terlizzi ME, Sidoti F, Solidoro P, Cavallo R: Detection of Mimivirus in bronchoalveolar lavage of ventilated and nonventilated patients. Intervirology 2012;55:303-305.

66 Yutin N, Colson P, Raoult D, Koonin EV: Mimiviridae: clusters of orthologous genes, reconstruction of gene repertoire evolution and proposed expansion of the giant virus family. Virol J 2013;10:106.

67 Colson P, de Lamballerie X, Fournous G, Raoult D: Reclassification of giant viruses composing a fourth domain of life in the new order Megavirales. Intervirology 2012;55: 321-332.

68 Ngounga T, Pagnier I, Reteno D-G I, Raoult D, La Scola B, Colson P: Real-time PCR systems targeting giant viruses of amoebae and their virophages. Intervirology 2013;56:413423.

69 Raoult D, Renesto P, Brouqui P: Laboratory infection of a technician by Mimivirus. Ann Intern Med 2006;144:702-703.

-70 Campos RK, Andrade KR, Ferreira PC, Bonjardim CA, La Scola B, Kroon EG, Abrahao JS: Virucidal activity of chemical biocides against Mimivirus, a putative pneumonia agent. J Clin Virol 2012;55:323-328.

71 Coulon C, Collignon A, McDonnell G, Thomas V: Resistance of Acanthamoeba cysts to disinfection treatments used in health care settings. J Clin Microbiol 2010;48:2689-2697.

72 Garcia MT, Jones S, Pelaz C, Millar RD, Abu $\mathrm{KY}$ : Acanthamoeba polyphaga resuscitates viable non-culturable Legionella pneumophila after disinfection. Environ Microbiol 2007;9: 1267-1277.

73 Cohen G, Hoffart L, La Scola B, Raoult D, Drancourt M: Ameba-associated Keratitis, France. Emerg Infect Dis 2011;17:1306-1308.
74 Desnues C, La Scola B, Yutin N, Fournous G, Robert C, Azza S, Jardot P, Monteil S, Campocasso A, Koonin EV, Raoult D: Provirophages and transpovirons as the diverse mobilome of giant viruses. Proc Natl Acad Sci USA 2012;109:18078-18083.

75 Lagier JC, Armougom F, Million M, Hugon P, Pagnier I, Robert C, Bittar F, Fournous G, Gimenez G, Maraninchi M, Trape JF, Koonin E, Koonin EV, La Scola B, Raoult D: Microbial culturomics: paradigm shift in the human gut microbiome study. Clin Microbiol Infect 2012;18:1185-1193.

76 Breitbart M, Rohwer F: Method for discovering novel DNA viruses in blood using viral particle selection and shotgun sequencing. Biotechniques 2005;39:729-736.

77 Loh J, Zhao G, Presti RM, Holtz LR, Finkbeiner SR, Droit L, Villasana Z, Todd C, Pipas JM, Calgua B, Girones R, Wang D, Virgin HW: Detection of novel sequences related to African swine fever virus in human serum and sewage. J Virol 2009;83:13019-13025.

-78 Yozwiak NL, Skewes-Cox P, Stenglein MD, Balmaseda A, Harris E, DeRisi JL: Virus identification in unknown tropical febrile illness cases using deep sequencing. PLoS Negl Trop Dis 2012;6:e1485.

79 Wylie KM, Mihindukulasuriya KA, Sodergren E, Weinstock GM, Storch GA: Sequence analysis of the human virome in febrile and afebrile children. PLoS One 2012;7:e27735.

80 Saadi H, Reteno D-G I, Colson P, Aherfi S, Minodier P, Pagnier I, Raoult D, La Scola B: Shan virus: a new Mimivirus isolated from the stool of a Tunisian patient with pneumonia. Intervirology 2013;56:424-429.

81 Ghigo E, Kartenbeck J, Lien P, Pelkmans L, Capo C, Mege JL, Raoult D: Ameobal pathogen mimivirus infects macrophages through phagocytosis. PLoS Pathog 2008;4:e1000087.

-82 Khan M, La Scola B, Lepidi H, Raoult D: Pneumonia in mice inoculated experimentally with Acanthamoeba polyphaga mimivirus. Microb Pathog 2007;42:56-61.
Giant Viruses of Amoebae as Human Pathogens
Intervirology 2013;56:376-385 DOI: $10.1159 / 000354558$ 